\title{
PENENTUAN KONDISI OPTIMUM FERMENTASI PADAT Trichoderma hamatum PADA MEDIA TUMBUH DEDAK PADI DALAM PRODUKSI SELULASE MENGGUNAKAN RESPONSE SURFACE METHODOLOGY
}

\section{OPTIMUM CONDITION FOR SOLID FERMANTATION OF Trichoderma Humatum IN RICE BRAN IN ORDER TO PRODUCE CELULASE BY USING RESPONSE SURFACE METHODOLOGY}

\author{
Teuku Beuna Bardant ${ }^{1}$, Haznan Abimanyu ${ }^{1}$, Putri Lili Epriyani ${ }^{2}$ \\ 1) Peneliti Pusat Penelitian Kimia-LIPI, Kawasan Puspiptek, Tangerang Serpong \\ ${ }^{2)}$ Mahasiswa Departemen Biokimia, Fakultas Matematika dan Ilmu Pengetahuan Alam, IPB \\ Email: qaismajnun@gmail.com
}

Diterima: 19 Agustus 2013, Direvisi: 2 Desember 2013, Disetujui: 10 Desember 2013

\begin{abstract}
ABSTRAK
Telah dilakukan penelitian untuk menentukan kondisi optimum fermentasi padat Trichoderma hamatum dalam media tumbuh dedak padi pada proses produksi selulase menggunakan Response Surface Methodology (RSM). Kondisi operasi yang diatur sebagai variable bebas adalahkadar air, kadar urea, dan kadar bibit.Parameter yang ditelaah adalah aktivitas selulase dari ekstrak media tumbuh dedak padi yang dinyatakan dalam FPU/gds (gram of dry solid). Persamaan empirik dari RSM yang diperoleh dari penelitian ini telah terbukti valid untuk rentang kondisi fermentasi pada rasio air terhadap dedak $0.5-0.75$, kadar urea 2\%-3\%, dan kadar bibit 1\%$2 \%$. Nilai aktivitas maksimum sebesar $4.99 \pm 0.92$ FPU/gds diperoleh dalam rentang kondisi optimum tersebut.
\end{abstract}

Kata Kunci : Selulase, Trichoderma hamatum, dedak padi, fermentasi padat.

\section{ABSTRACT}

Optimum condition for solid fermentation of Trichoderma hamatum in rice bran in order to produce cellulase had been studied by using Response Surface methodology (RSM). Fermentation condition variables that observed was water to rice bran ratio, urea and inoculums additions cellulase activity in FPU/gds (gram of dry solid) became the only dependent variable. The result of empirical equation from this study was proven to be valid within water to rice bran ratio 0,5 - 0,7, urea and inoculums addition where 2-3\% and 1-2\% of rice bran weight respactively. Maximum cellulase activity that can be obtain within these ranges was $4.99 \pm 0.92 \mathrm{FPU} / \mathrm{gds}$.

Keywords : Cellulase, Trichoderma hamatum, rice bran, solid fermentatio 


\section{PENDAHULUAN}

Selulase merupakan suatu enzim yang dapat memecah selulosa menjadi glukosa dengan cara memutuskan ikatan glikosidik $\beta-1,4$ yang terdapat pada selulosa, sedodekstrin, selobiosa, dan lain-lain. Enzim ini termasuk ke dalam golongan enzim hidrolase ${ }^{(1)}$. Selulase dihasilkan oleh beberapa mikroorganisme seperti Aspergillus niger dan Aspergillus fumigatus.

Saat ini selulase banyak digunakan dalam berbagai industri. Pada industri peternakan, selulase ditambahkan dalam pakan untuk menaikkan tingkat kecernaan pakan serta meningkankan nilai gizi pakan $^{(2,3)}$. Pada industri pertanian, selulase digunakan sebagai biokontrol dalam melawan jamur perusak tanaman ${ }^{(4)}$. Pada industri kertas, selulase digunakan sebagai bahan pemúcat alami (biobleaching) dalam proses pemutihan $\operatorname{kertas}^{(5)}$. Di industri tekstil, selulase dapat digunakan sebagai bahan penurun bobot kain katun ${ }^{(6)}$.

Pemanfaatan selulase tersebut dihambat oleh tingginya harga selulase komersial yang ada di pasaran saat ini. Sehingga industri atau perusahaan lebih memilih menggunakan bahan-bahan kimia lain yang memiliki fungsi sama. Namun, penggunaan bahan-bahan kimia tersebut menimbulkan dampak pencemaran lingkungan yang besar dan memprihatinkan. Penelitian ini merupakan salah satu usaha untuk merancang proses produksi enzim selulase yang murah dengan aktivitas selulase yang sesuai kebutuhan.

Salah satu mikroorganisme penghasil selulase yang baik adalah Trichoderma sp. Trichodermasp. Merupakan suatu jenis jamur yang masuk ke dalam kelas Ascomycetes yang banyak terdapat di dalam tanah dan tumbuhan berkayu ${ }^{(7)}$. Jamur Trichoderma sp. telah dikenal luas oleh masyarakat Indonesia pengendali penyakit tanaman karena aktivitasnya sebagai mikroorganisme antagonis yang merugikan mikroorganisme lainnya, terutama mikroorganisme yang bersifat parasit terhadaptumbuhan ${ }^{(8)}$. Telah banyak industri pertanian yang memproduksi Trichoderma sebagai biofungisida.

Selain sebagai biofungisida, Trichoderma juga dikenal sebagai mikroorganisme penghasil selulase yang baik. Beberapa spesies Trichoderma seperti T. reesei, T. citrinoviride, T.viride, T. harzianum, dan $T$. atroviride. Pada penelitian ini spesies Trichoderma yang digunakan adalah Trichoderma hamatum. Trichoderma hamatum sendiri lebih dikenal sebagai agen pengendali fungi patogen atau sebagai biofungisida. Namun, berdasarkan penelitian diketahui bahwa Trichoderma hamatum dapat hidup dalam media agar selulotik yang menunjukan 
bahwa spesies ini dapat menghasilkan selulase $^{(27)}$.

Proses fermentasi substrat padat dapat digunakan untuk produksi selulase. Fermentasi substrat padat merupakan suatu metode fermentasi yang memungkinkan penggunaan bahan-bahan limbah pertanian sebagai media atau substrat tumbuh jamur. Pada proses ini substrat yang digunakan tidak harus larut di alam air melainkan memiliki kandungan air yang cukup. Selain itu, fermentasi substrat padat juga memiliki beberapa keuntungan seperti lebih sederhana, produktivitas volumetrik lebih tinggi, konsentrasi produk lebih tinggi, waktu fermentasi lebih singkat, aktivitas protease rendah, spora yang dihasilkan akan lebih stabil, resisten terhadap kekeringan, serta tingkat perkecambahan yang lebih tinggi walaupun setelah mengalami pengeringan beku dalam waktu yang lama ${ }^{(9)}$. Keuntungan lain yang dapat diperoleh seperti konsumsi energi yang rendah, kebutuhan air rendah, koefisien perpindahan massa tinggi, tidak berbusa, konsentrasi produk dapat dipertahankan (10), tingkat kontrol pada proses produksi, dan tingkat konsistensi proses juga tinggi (11). Terdapat beberapa faktor utama yang mempengaruhi proses fermentasi padat yaitu $\mathrm{pH}$, suhu, waktu fermentasi, kadar air, dan ketersedian nutrisi. Keadaan udara, inducer, ketebalan biakan juga dapat mempengaruhi proses fermentasi padat ${ }^{(12,}$ 13). Pada penelitian ini faktor utama yang menjadi perhatian adalah kadar air dan ketersediaan nutrisi, sedangkan $\mathrm{pH}$, temperatur, dan waktu fermentasi dijadikan faktor tetap.

Media atau substrat yang digunakan dalam penelitian ini adalah dedak padi. Dedak padi merupakan suatu hasil ikutan pengolahan padi (Oryza sativa) menjadi beras. Penyusun utama dedak padi adalah lapisan kulit ari padi. Penggilingan satu ton gabah dapat menghasilkan dedak padi sebanyak $60-80 \mathrm{~kg}{ }^{(14)}$. Dedak padi mengandung protein (11-17\%), lemak (2.52-5.05\%), karbohidrat (58-72\%), dan serat ${ }^{(15)}$. Alasan penggunaan dedak padi sebagai media fermentasi antara lain karena dedak padi merupakan limbah hasil pertanian yang pemanfaatannya belum maksimal, memiliki kandungan selulosa yang tinggi, serta jaminan ketersediaan yang dapat diandalkan sebagai hasil samping dari makanan pokok utama di Indonesia. Selain itu, pemilihan dedak padi sebagai media juga berdasarkan beberapa penelitian terdahulu yang menunjukan bahwa limbah tanaman serelia merupakan media yang sangat baik untuk pertumbuhan mikroorganisme penghasil selulase $^{(16,17)}$. Pusat Penelitian Kimia LIPI juga pernah menggunakan dedak padi sebagai media tumbuh bagi 
Rhizopusoligosporus untuk memprodusi lipase $^{(18)}$.

Nutrisi yang diperlukan Trichoderma hamatumantara lain sumber $\mathrm{C}$, sumber $\mathrm{N}$, dan air. Sumber $\mathrm{C}$ telah didapatkan Trichoderma hamatum dari dedak padi, sedangkan sumber $\mathrm{N}$ dapat dipenuhi oleh penambahan urea serta NPK ke dalam biakan. Namun, hingga kini belum tersedia acuan yang handal untuk menentukan banyaknya penambahan urea, air serta bibit Trichoderm ahamatum yang digunakan agar mendapat nilai aktivitas selulase yang optimum. Salah satu metode yang dapat digunakan untuk membuat acuan kondisi operasi proses adalah Response Surface Methodology (RSM). RSM berguna untuk menganalisis dampak yang melibatkan beberapa variabel respon dengan tujuan untuk mengoptimalkan dampak $^{(19)}$. Tujuan dari penelitian ini adalah menentukan kondisi optimum fermentasi padat Trichoderma hamatum untuk produksi selulase menggunakan Response Surface Methodology (RSM).

\section{BAHAN DAN METODA}

\section{Bahan}

Bibit Trichoderma hamatum yang digunakan dalam penelitian ini adalah Trichoderma hamatum yang telah dikembangkan pada skala komersial untuk biofungisida oleh $\mathrm{CV}$ Wish Indonesia, Bogor dengan nama dagang Trichowish. Dedak padi, NPK dan urea dibeli di pasar local sekitar wilayah PUSPIPTEK Serpong tanpa ada criteria tertentu, serupa dengan apabila barang yang sama dibeli di daerah lain. Bahan kimia untuk analisa gula sesuai NREL dan SNI 01-2891-1992 yaitu natrium bikarbonat, asam sitrat, asam sulfat, kalium iodida, natrium tiosulfat adalah bahan-bahan kimia dengan criteria untuk analisa (pro analytic (p.a)) produksi Merck.

\section{Peralatan}

Sterilisasi dedak menggunakan oven bertenaga listrik pada suhu $105^{\circ} \mathrm{C}$. Proses pemanasan pada suhu $45{ }^{\circ} \mathrm{C}$ untuk keperluan pengukuran aktivitas selulase menggunakan pemanas listrik untuk laboratorium. Inkubasi dilakukan dalam ruang incubator rakitan PP Kimia meggunakan daya listrik 60 Watt untuk memanaskan ruang bervolume 150 liter. Perangkat gelas untuk titrasi dan preparasi sampel untuk pengukuran aktivitas selulase diproduksi Pyrex.

\section{Metoda}

Pembiakan Trichoderma hamatum dilakukan pada dedak padi dengan kombinasi variable bebas yang sebagaimana ditampilkan dalam Tabel 1 . Sebanyak 50 gram dedak padi steril 
dijadikan sebagai berat acuan untuk setiap percobaan. Pencampuran pertama dilakukan antara larutan urea ke dalam dedak padi steril, kemudian ke dalam campuran tersebut ditambahkan bibit Trichoderma hamatum, diaduk kembali hingga rata. Campuran kemudian dimasukan ke dalam kantung plastik, dan dilubangi bagian atas dan bawahnyadengan jarak antar lubang $\pm 1,5$ cm sebagai tempat pertukaran udara. Fermentasi padat pada media tanam dalam plastik-plastik tersebut dilakukan pada suhu $31-35{ }^{\circ} \mathrm{C}$ selama 7 hari.

Hasil fermentasi padat ditimbang bobotnya dan diekstraksi dengan rasio berat penambahan air dan bobot setelah fermentasi sebesar 1:1. Volume hasil penyaringan dicatat. Sebagian dari sampel ekstrak yang diperoleh diatur $\mathrm{pH}$-nya hingga mencapai 5, lalu diukur aktivitas selulasenya dengan menggunakan metode NREL $^{(20)}$. Kadar glukosa yang terbentuk diukur menggunakan metode Luff Schrool (SNI 01-2891-1992).

Tabel.1. Kombinasi variable bebas yang digunakan untuk mendapatkan persamaan empirik melalui RSM

\begin{tabular}{ccc}
\hline $\begin{array}{c}\text { Rasio air } \\
\text { dalamdedak }\end{array}$ & $\begin{array}{c}\text { urea } \\
(\boldsymbol{\%} \text { w dedak })\end{array}$ & $\begin{array}{c}\text { bibit } \\
\text { (\%w dedak })\end{array}$ \\
\hline 0.5 & 0 & 2 \\
\hline 1 & 0 & 2 \\
\hline 1 & 2 & 3 \\
\hline 1.5 & 0 & 1 \\
\hline 1.5 & 4 & 2 \\
\hline 0.5 & 0 & 1 \\
\hline 1 & 2 & 2 \\
\hline 0.5 & 2 & 3 \\
\hline 1.5 & 4 & 3 \\
\hline 1 & 0 & 2 \\
\hline 0.5 & 4 &
\end{tabular}

Nilai FPU yang diperoleh akan digunakan sebagai variabel terikat dalam penentuan persamaan empiric polynomial orde dua menggunakan program SPSS. Variabel respon yang digunakan adalah kadar urea, air, dan bibit yang digunakan. Persamaan yang telah didapat divisualisasikan menjadi grafik 3D menggunakan program Mathcad. Pada grafik 3D ditentukan titik-titik optimum yang akan digunakan dalam proses validasi persamaan.

Validasi persamaan dilakukan menyelenggarakan fermentasi padat pada 
kombinasi variable bebas yang memberikan aktivitas selulase optimum berdasarkan persamaan empiris. Apabila aktivitas selulase dari ekstrak hasil fermentasi padat tersebut sama atau lebih tinggi daripada nilai aktivitas selulase yang diperkirakan oleh persamaan empiris, maka persamaan tersebut dianggap valid.

\section{HASIL DAN PEMBAHASAN}

Persamaan Empirik Hasil Response

Surface Methodology (RSM)
Response Surface Methodology atau RSM merupakan suatu metode yang dapat digunakan untuk mengetahui keterkaitan antara tiga atau lebih variabel pada suatu dampak. Metode ini dapat digunakan untuk mengetahui secara langsung keterkaitan antara satu variabel dengan variabel lain. Metode ini juga dapat mempermudah penelitian dengan meminimalkan jumlah sampel yang akan diuji. Hal ini sangat berguna jika waktu penelitian tersedia sangat singkat ${ }^{(19)}$.

Tabel 2. Hasil Pengukuran FPU dan perhitungan persamaan empiris

\begin{tabular}{ccccc}
\hline & Variabelbebas & \multicolumn{2}{c}{ FPU / gds } \\
\hline $\begin{array}{c}\text { Rasio } \\
\text { air }\end{array}$ & $\begin{array}{c}\text { Urea } \\
(\mathbf{\% w})\end{array}$ & $\begin{array}{c}\text { Bibit } \\
(\%)\end{array}$ & Hasilukur & Hasilhitung \\
\hline 0.5 & 0 & 2 & 2.025 & 2.458 \\
\hline 1 & 0 & 2 & 1.626 & 2.219 \\
\hline 1 & 2 & 3 & 2.556 & 2.675 \\
\hline 1.5 & 0 & 1 & 1.368 & 2.207 \\
\hline 1.5 & 4 & 2 & 2.233 & 2.432 \\
\hline 0.5 & 0 & 1 & 2.705 & 2.494 \\
\hline 1 & 2 & 2 & 3.005 & 2.956 \\
\hline 0.5 & 2 & 3 & 2.774 & 2.980 \\
\hline 1.5 & 4 & 3 & 4.254 & 2.353 \\
\hline 1 & 0 & 3 & 2.143 & 2.030 \\
\hline 0.5 & 4 & 2 & 3.624 & 3.574 \\
\hline
\end{tabular}

Pada penelitian ini, faktor-faktor atau variabel respon yang diperhatikan dalam penentuan aktivitas enzim selulase adalah kadar air, urea, serta bibit. Ketiga variabel respon disusun dalam sebuah persamaan polynomial orde dua yang dapat digunakan untuk menentukan nilai aktifitas enzim selulase dari Trichoderma hamatum pada media dedak padi (persamaan 1). Perbedaan nilai tebakan persamaan 
tersebut terhadap nilai hasil pengukuran dapat dilihat pada Tabel 2. Nilai tebakan memiliki $\mathrm{R}^{2}$ sebesar $94.7 \%$ terhadap nilai hasil ukur sebenarnya yang menunjukkan bahwa persamaan dapat menjelaskan keterkaitan antara ketiga variabel terhadap variable dampak, yang dalam hal ini adalah aktivitas selulase. Persamaan yang didapatkan divisualisasikan dengan menggunakan kurva 3D (Gambar 1).

$$
\begin{aligned}
F p u & =3,689-3,991 \text { air }+1,090 \text { urea }+0,341 \text { bibit }+1,557 \text { air }^{2}-0,135 \text { urea }^{2}-0,224 \text { bibit }^{2} \\
& -0,361 \text { airurea }+0,588 \text { airbibit }-0.046 \text { ureabibit }(1)
\end{aligned}
$$

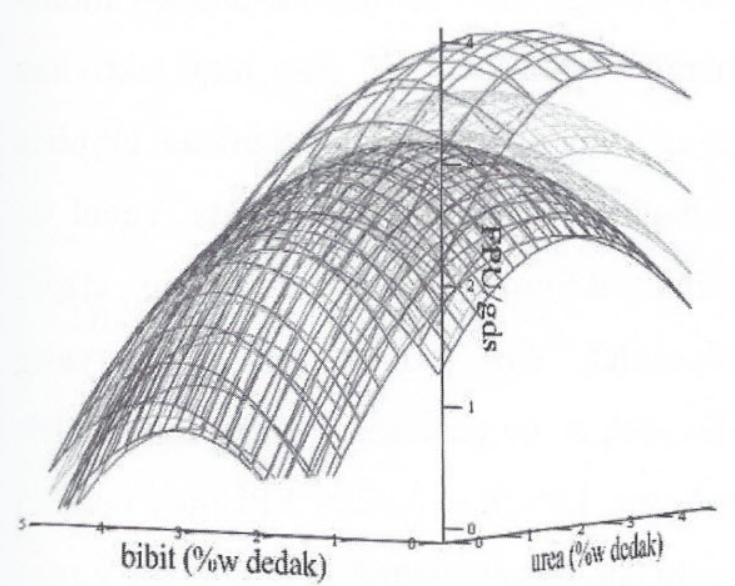

Keterangan : Merah : air 0,5 Kuning : air 0,7

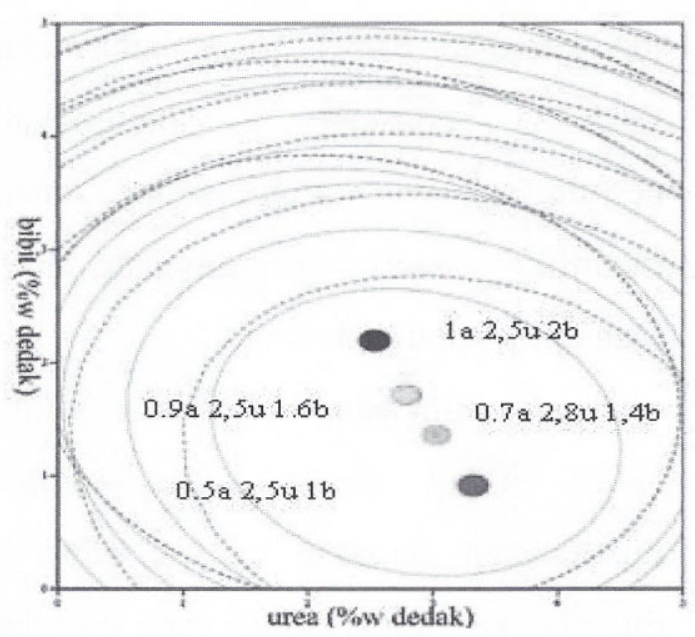

Hijau: air 0,9 Biru: air 1

Gambar 1. Kurva 3D persamaan empirik RSM

Untuk setiap variabel yang diuji, yaitu kadar air, kadar urea dan kadar bibit, penambahan nilai masing-masing variable akan menaikan nilai aktivitas selulase yang diperoleh hingga mencapai suatu titik optimum. Penambahan nilai variabel di atas titik tersebut menyebabkan penurunan aktivitas enzimnya. Pada variabel kadar air, semakin banyak air yang ditambahkan maka posisi kurva akan semakin di bawah. Berdasarkan nilai aktifitas enzim yang dihasilkan diketahui bahwa kadar air yang baik adalah sekitar 50\%-75\% bobot kering dedak padi, sedangkan penambahan air di atas $75 \%$ akan menyebakan penurunan nilai aktivitas. Hasil ini sesuai dengan hasil penelitian sebelumnya, yamg menunjukan bahwa kadar air yang baik untuk pembiakan Trichoderma.sp adalah besar $50-70 \%{ }^{(21)}$. Alasan yang paling mungkin adalah karena dedak padi memiliki keterbatasan dalam menyerap air. Penambahan air diatas kapasitas maksimum dedak dalam menyerap air akan menyebabkan jamur sulit tumbuh 
serta meningkatkan peluang tumbuhnya kontaminan lainnya terutama bakteri ${ }^{(22)}$.

Pada penambahan kadar urea, kadar urea yang baik ditambahkan ke dalam kultur adalah sekitar 2\%-3\% bobot kering media. Penambahan urea di atas 3\% akan menyebabkan penurunan nilai aktivitas enzim selulase yang didapatkan. Hal ini sejalan dengan prinsip pertanian yang menyebutkan bahwa penambahan pupuk tidak serta-merta meningkatkan pertumbuhannya karena setiap tanaman memiliki batas kemampuan dalam menyerap pupuk tersebut.

Kadar bibit yang baik adalah sekitar 1 $\%-2 \%$ bobot media kering. Hal ini dikarenakan semakin banyak bibit yang ditambahkan maka waktu yang diperlukan untuk fermentasi semakin singkat. Pada penelitian ini, waktu inkubasi dianggap sebagai variabel tetap yaitu tujuh hari, sehingga jika bibit yang dimasukan banyak makapada hari ketujuh Trichoderma hamatumtelah melewati fase produktifnya. Jika fase produktifnya telah terlewati maka selulase yang dihasilkan pun akan turun.

\section{Validasi Persamaan Empirik}

Proses validasi dilakukan terhadap lima titik optimum yang memiliki nilai aktivitas berbeda-beda. Nilai optimum yang digunakan merupakan titik puncak setiap kurva 3D dari persamaan empirik yang dihasilkan oleh RSM sebagaimana tergambar dalam Gambar 1. Proses validasi menyatakan bahwa pada rentang kadar air sebesar 50\%-150\%, kadar urea 0\%-4\%, serta kadar bibit 1\%-3\% tingkat ketepatan dugaan hasil aktivitas selulase pada ekstrak oleh persamaan empiris dapat diterima. Nilai aktivitas enzim selulase hasil pengukuran pada saat penyelenggaraan fermentasi untuk validasi berada tepat atau di atas nilai aktivitas yang ditentukan oleh persamaan empiris sebagaimana ditampilkan pada Tabel 3 . Nilai aktivitas maksimum yang dapat diperoleh dari komposisi nutrisi yang ditentukan berdasarkan persamaan adalah sebesar 4,9929 $\pm 0,9204 \mathrm{FPU} / \mathrm{gds}$ dengan rasio air terhadap dedak 0,$5 ; 2,5 \%$ kadar urea, dan 2\% kadar bibit.

\section{Perbandingan Aktivitas Selulase}

\section{Terhadap Hasil Penelitian Sebelumnya}

Nilai aktivitas selulase yang didapatkan pada penelitian ini serupa dengan beberapa nilai aktivitas yang diperoleh pada penelitian-penelitian sebelumnya sebagaimana ditunjukkan pada Tabel 4. Kesesuaian dedak padi sebagai media tanam untuk produksi selulase sebanding dengan kulit kedelai dan kulit gandum dan lebih baik dari ampas tebu dan kulit jeruk. Hasil penelitian ini juga menunjukan bahwa 
Trichoderma hamatum merupakan salah satu spesies Trichoderma yang dapat menghasilkan selulase dengan aktivitas yang baik jika dibandingkan dengan spesies lainnya (Tabel 5). Trichoderma

Tabel 4. Perbandingan nilai aktivitas enzim selulase

\begin{tabular}{|c|c|c|c|}
\hline Peneliti & Mikroorganisme & Media Tumbuh & FPU/gds \\
\hline \multirow{4}{*}{$\begin{array}{c}\text { Debalona et al. } \\
2012^{(16)}\end{array}$} & \multirow[t]{4}{*}{ A.niger } & Kulit kedelai $(60 \%)$ & 5.6 \\
\hline & & Kulit gandum (50\%) & 2.9 \\
\hline & & Ampas jeruk $(70 \%)$ & 0.9 \\
\hline & & $\begin{array}{l}\text { Ampas tebu : kulit gandum } \\
(1: 1)\end{array}$ & 2.2 \\
\hline \multirow{3}{*}{ - } & \multirow[t]{3}{*}{ A.fumigatus } & Kulit kedelai $(60 \%)$ & 2.4 \\
\hline & & Kulit gandum (50\%) & 5.0 \\
\hline & & $\begin{array}{l}\text { Ampas tebu : kulit gandum } \\
(1: 1)\end{array}$ & 5.1 \\
\hline \multirow[t]{5}{*}{$\begin{array}{l}\text { Dhillon et al. } \\
\qquad 2011^{(17)}\end{array}$} & \multirow[t]{4}{*}{ A.niger } & Ampas kembang kol & 8.39 \\
\hline & & Ampas kacang polong & 8.74 \\
\hline & & Kinnow & 8.44 \\
\hline & & Jerami Padi & 9.02 \\
\hline & $\begin{array}{l}\text { Thermoascus } \\
\text { aurantiacus }\end{array}$ & Jerami gandum & 5.5 \\
\hline
\end{tabular}

hamatum yang dibiakan dengan komposisi $50 \%$ air, $0 \%$ urea, dan $1 \%$ bibit dapat menghasilkan enzim selulase dengan aktivitas 0,7992 FPU/mL.

Mikroba alami hanya mampu menghasilkan selulase dengan aktivitas $\begin{array}{llll}\text { sebesar } & 0.5-9 \quad \text { FPU/gds. Untuk }\end{array}$ mendapatkan enzim selulase dengan aktivitas yang lebih tinggi dapat dilakukan dengan menggunakan mikroba mutan. Penelitian yang menggunakan mikroba mutan telah dilakukan pada beberapa penelitian sebelumnya dan menunjukan peningkatan aktivitas yang sangat pesat.

Tabel 5. Perbandingan nilai aktivitas enzim selulase antar spesies Trichoderma

\begin{tabular}{ccc}
\hline Peneliti & Spesies Trichoderma & Nilai FPU (FPU/mL) \\
\hline Gadgill et al. $1995^{(25)}$ & T. reesei & 0.04 \\
Chandra et al. $2009^{(26)}$ & T. citrinoviride & 0.63 \\
Zhou et al. $2008^{(27)}$ & T.viride & 0.88 \\
\hline
\end{tabular}


Dhillon et al. $2008^{(28)}$

Kovacs et al. 2008 ${ }^{(29)}$
T. harzianum

T. atroviride
1.5

0.41
Terdapat beberapa contoh spesies mikroba yang telah dilakukan pembiakan mutannya, antara Trichoderma reesei MGG77, Trichoderma reesei ZU-02, Trichoderma reesei RUT C30, Trichoderma koningi F244, Funalia trogi IBB146, Aspergillus niger KK2, dan Aspergillus terrus M11 ${ }^{(17,23,24)}$.

\section{KESIMPULAN}

Kondisi optimum fermentasi padat Trichoderma hamatum untuk produksi selulase dapat dipetakan dengan menggunakan RSM. RSM dapat menggambarkan secara langsung keterkaitan antara kadar air, urea, dan bibit terhadap nilai aktivitas enzim selulase. Persamaan empiris yang diperoleh dapat diterima berdasarkan hasil validasi pada lima titik optimum. Berdasarkan persamaan empirisnya, diketahui bahwa rentang kondisi optimum pertumbuhan Trichoderma hamatum pada media dedak padi adalah pada kadar air 50\%-75\%, kadar urea 2\%-3\%, dan kadar bibit 1\%$2 \%$. Dengan nilai aktivitas maksimum sebesar $4.9929^{\circ} \pm 0.9204 \mathrm{FPU} / \mathrm{gds}$.

Penelitian ini juga menunjukan bahwa dedak padi merupakan suatu limbah pertanian yang dapat digunakan sebagai media pertumbuhan jamur untuk produksi selulase dengan nilai aktivitas yang baik. Serta Trichoderma hamatum dapat dimasukkan ke dalam kategori spesies Trichoderma yang dapat menghasilkan enzim selulase dengan aktivitas yang baik.

\section{UCAPAN TERIMA KASIH}

Terimakasih dan penghargaan setinggitingginya disampaikan kepada seluruh peserta Seminar Nasional Kimia Terapan Indonesia (SNKTI) 2013 atas saran yang telah diberikan untuk tulisan ini, kepada Prof. Dr. H. Buchari yang telah menjadi Tim Mitra Bestari bagi JKTI untuk penyempurnaan tulisan ini, dan kepada Bapak Ir. Suhermanto selaku pimpinan redaksi JKTI atas jerih-payahnya memandu jurnal ini hingga tahap penerbitannya.

\section{DAFTAR PUSTAKA}

1. Roswiem AP et al. 2002. Biokimia Umum Jilid 1. Bogor (ID): Departemen Biokimia-FMIPA Institut Pertanian Bogor

2. Szijarto N, Zsofia F, Kati R, Miklus M, Andias B. 2004. Cellulase fermentation on a novel substrate (waste cardboard) and subsequent utilization of home-produced cellulase and commercial amylase in a feeding trial. J.Indcrop 20: 49-57. 
3. Graminha EBN, et al. 2008. Enzyme productionby solid state fermentation aplication to animal nutrition. $J$. Anifeedsci 144: 1-22.

4. Mohamed H.A.A, Haggag W, AG Attalah. Genetic enhancement of Trichoderma viride to overproduce different hydrolytic enzymes and their biocontrol potentiality against root rot and while mold discuses in bean plants. J.N.AM 1(3): 273-284.

5. Szendefy J, G Szakaes, L Christopher. 2006. Potential of solidstate fermentation enzymes of Aspergillus oryzae in biobleaching of paper pulp. J.Enzmictec 39 : 13541360.

6. Lima A.L.G, Rodrigo P.N, Elba P.S.B, Rosalie R.R.C. 2005. Sterptomyces drozdowiczil cellulase production using agro-industrial byproducts and its potential use in the detergent and textile industries. $J$. Enzmicted 37: 272-277.

7. Semangun, H., 2000. PenyakitPenyakit Tanaman Hortikultura di Indonesia. Yogyakarta (ID): Gadjah Mada University Press.

8. Purwantisari dkk. 2004. Uji potensi jamur antagonis Trichoderma (ignorant sebagai agen pengendali hayati jamur patogen Phytoplahora infestans penyebab penyakit utama tanaman Kentang [Skripsi]. Semarang: Universitas Diponegoro.

9. Holker U, Jurgen L. 2005. Solid-state fermentation- are there any biotechnological advantages?. Microbiology 8:301-306.

10. Suryanarayan S. 2003. Current industrial practice in solid state fermentations for secondary metabolite production : the Biocon India experience. J.Biochemical engineering 13:189-195.

11. Oojikaas LP, Frans JW, Reinetta MB, Jahannes T, Arjen R. 2000. Defined media and inert supports: their potential as solid-state fermentation production systems. TIBTECH. Vol.18:356-360.

12. Fujian Xu, Chen H, Li Z. 2002. Effect of periodically dynamic changes of air on cellulase productions in solid-state fermentation. Enzyme and Microbial Technol. 30:45-48.

13. Singhania RR, Rajeev KS, Anil KP, Christian L, Ashok P. 2010. Advancement and comparative profile in the production technologies using solid-state and submerged fermentation for microbial cellulases. Enzyme and Microbial Technol. 46:541-549.

14. Dewan Standarisasi Nasional. 1996. Dedak padi/bahan baku pakan. SNI 01-3178-1996/Rev. 92. Jakarta: Dewan Standarisasi Nasionala DSN.

15. Suparyono, A. Setyono. 1997. Mengatasi Permasalahan Budi Daya Padi. Jakarta (ID): Penebar Swadaya.

16. Delabona P, Rosangela DPBP, Carla AC, Celia RT, Andre R, Cristiane SF. 2012. Using amazon forest fungi and agricultural residues as a strategy to produce cellulolytic enzymes. Biomass and Bioenergy 37: 243-250.

17. Dhillon GS, Harinder SO, Surinder K, Sunil B, Satinder KB. 2011. Value-addition of agricultural wates for augmented cellulase and xylanase production through solid sate tray fermentation employing mixed cultural of fungi. J.Indcrop34 : 1160 1167. 
18. Bardant, Teuku Beuna, Kiky Corneliasari Sembiring, and Achmad Hanafi Setiawan. 2007. Preliminary studies for producing crude lipase from tempe'smouldcultivated in rice-husk-based solid media Indo. $J$. Chem., 2007, 7 (2), 223-229

19. Bardley N. 2007. The responses surface methodology [Tesis]. South Bend : Indiana University.

20. Adney B, J. Baker. 2008. Measure of Cellulase Activities Laboratory Analitical Procedure (LAP). Technical Report NREL/TP-51042628.

21. Latifian M, Zohreh HE, Mohsen B. 2007. Evaluation of culture conditions for cellulase production by two Trichoderma reesei mutants under solid-state fermentation condition. Bioresource Technol. 98: 3634-3637.

22. Domsch, K.H., dan W. Gams. 1972. Fungi in Agricultural Soils. London (GB): Longman Group Limited Publishing.

23. Sukumaran RK, Reeta RS, Gincy MM, Ashok P. 2009. Cellulase production using biomassa feed stock and its apllication in lignocellulose saccharification for bio-ethanol production. J.renene 34: 421-424.

24. Gao J, Haibo W, Daheng Z, Mingxue Y. Fanghia G, Yu X. 2008. Production and characterizatition of cellulolytic enzymes from the thermoacidophilic fungal Aspergillus terreus M11 under solid-state cultivation of corn stover. J.biortech 99: 7623-7629.
25. Gadgil NJ, Daginawal HF, Chakrabati T, Khanna P. 1995. Enhanced cellulase production by a mutant of Trichoderma reesei. Enzyme Microb. Technol. 17: 942946.

26. Chandra M, Alok K, Neelam SS, Shailendra SG, Mahender PD, Rajinder SS. 2009. Development of a mutant of Trichoderma citrinoviridefor enhanced production of cellulases. Bioresource Technol. 100: 1659-1662.

27. Zhou J, Yong-Hong W, Ju C, YingPing Z, Si-Liang Z, Peng Y. 2008. Identification and purification of the main components of cellulases from a mutant strain of Trichoderma viride $\mathrm{T} \quad 100-14$ Bioresource Technol. 99: 6826-6833.

28. Dillon AJP, Marli C, Joao APH, Maria HPF, Andreia CSA, Tarciso AFV, Sergia CL. 2008. Generation of recombinants strains to cellulases production by protoplast fusion between Penicillium echinulatum and Trichoderma harzianum. Enzyme and Microbial Technol. 43:403-409.

29. Kovacs K, Laszlo M, George S, Christian PK, Mats G, Guido Z. 2008. Trichoderma atroviride mutants with enhanced production of cellulase and $\beta$-glucosidase on pretreated willow. Enzyme Microb. Technol. 43: 48-55.

30. Widyastuti S.M., Sumardi, A. Sulthoni, Supriyanto. 1999. Pemanfaatan biofungisida Trichoderma spp., untuk memepercepat penguraian serasah Acacia mangium. Mediagama 1(10):13-20 